\title{
Kimia Fisik Perairan dan Ektoparasit Ikan Nila dan Patin Di Situ Gintung, Tangerang Selatan, Banten
}

\author{
Dinda Rama Haribowo ${ }^{a, b^{*}}$, Syifa Annisa ${ }^{b, c}$, Nur Kholidahe, , Nia Dzirwatul Izza ${ }^{b, c}$, \\ Pratiwi Amalia Zahrah ${ }^{\mathrm{b}, \mathrm{c}}$, Ario Putro Pamungkas ${ }^{\mathrm{cd},}$, Firdaus Ramadhan ${ }^{\mathrm{a}, \mathrm{b}}$, \\ Alfan Farhan Rijaluddin ${ }^{\mathrm{b}}$, Yayan Mardiansyah Assuyuti ${ }^{\mathrm{b}}$ \\ ${ }^{a}$ Laboratorium Ekologi, Pusat Laboratorium Terpadu, UIN Syarif Hidayatullah, \\ bProgram Studi Biologi, Fakultas Sains dan Teknologi, UIN Syarif Hidayatullah \\ 'Kelompok Studi Generation of Microbiology and Molecular (GENOM), Program Studi Biologi, Fakultas Sains dan Teknologi, UIN Syarif \\ Hidayatullah \\ ¿Balai Benih Ikan Ciganjur, Pusat Produksi Inspeksi Sertifikasi Hasil Perikanan, Provinsi DKI Jakarta \\ * Penulis koresponden. Tel.: +62-813-181-03813 \\ Alamat e-mail: dindarama.haribowo@uinjkt.ac.id
}

Diterima (received) 2 November 2018; disetujui (accepted) 9 Mei 2019; tersedia secara online (available online) 12 Mei 2019

\begin{abstract}
Poor water quality based on physical and chemical waters is one of the factors that influence the infection and presence of fish ectoparasites. The aim of study was to determine the physical and chemical waters, the types and prevalence of ectoparasites and the correlation of ectoparasites with physical and chemical waters. The study was conducted in Situ Gintung, South Tangerang from March to June 2018 with samples from Floating Net Cages (KJA) and fishing. The results showed that the physical and chemical waters generally within standard quality for fish cultivation. The number and type of fish ectoparasites consist of Trichodina sp., Chilodonella sp., Litonotus sp., Vorticella sp., Dactylogyrus sp. and Capillaria sp. Based on the Canonical Correspondence Analysis (CCA) shows that ectoparasites are affected by physical and chemical waters.
\end{abstract}

Keywords: water quality; ectoparasites; situ gintung; CCA

\begin{abstract}
Abstrak
Kualitas perairan yang buruk berdasarkan kimia fisik adalah salah satu faktor yang mempengaruhi infeksi dan kehadiran ektoparasit ikan. Tujuan penelitian ini adalah untuk mengetahui kimia fisik perairan, jenis-jenis ektoparasit, prevalensi ektoparasit dan hubungan ektoparasit ikan dengan kimia fisik perairan. Penelitian dilakukan di Situ Gintung, Tangerang Selatan dari bulan Maret sampai dengan Juni 2018 dengan sampel berasal dari Keramba Jaring Apung (KJA) dan hasil memancing. Hasil penelitian menunjukkan bahwa kimia fisik perairan secara umum masih berada dalam rentang nilai standar baku mutu untuk budidaya ikan. Jumlah dan jenis ektoparasit ikan terdiri dari Trichodina sp., Chilodonella sp., Litonotus sp., Vorticella sp., Dactylogyrus sp. dan Capillaria sp. Berdasarkan Canonical Correspondence Analysis (CCA) menunjukkan bahwa ektoparasit dipengaruhi oleh kimia fisik perairan.
\end{abstract}

Kata Kunci: kualitas perairan; ektoparasit; situ gintung; CCA

\section{Pendahuluan}

Danau atau situ menyediakan berbagai macam fungsi dan layanan seperti sumber air minum, rekreasi, berenang, memancing, budidaya ikan dan populasi habitat flora dan fauna yang memiliki nilai ekonomi yang tinggi (Reynaud dan
Lanzanova, 2017). Selain memiliki keuntungan berdasarkan nilai ekonomi, fungsi dan layanan tersebut memiliki kerugian terhadap ekosistem danau seperti menurunnya kualitas perairan (Kagalou et al., 2003), meningkatnya polusi di air (Chen et al., 2016; Su et al., 2016), berpotensi mengganggu terhadap kesehatan manusia (Zhang 
et al., 2009), dominansi biota, keanekaragaman yang menurun (Cai et al., 2012) jika dibandingkan dengan danau yang tidak ada gangguan antropogenik (Lange et al., 2013) dan mempengaruhi keberadaan parasit di ikan (Lacerda et al., 2018).

Situ Gintung adalah salah satu danau di Kota Tangerang Selatan yang digunakan sebagai tempat rekreasi, memancing, keramba jaring apung (KJA) dan penampung hasil limbah rumah tangga. Hasil penelitian sebelumnya menunjukkan bahwa perairan Situ Gintung berada di luar baku mutu air minum dan telah tercemar (Bahri dkk., 2015; Wardhana dkk., 2017). Kualitas perairan situ atau danau yang tercemar menyebabkan kesehatan fauna seperti ikan menurun dan keberadaan parasit yang meningkat. Ikan di Situ Gintung yang dibudidaya adalah Patin sedangkan yang umum ditemukan dari aktivitas memancing adalah Nila. Budidaya ikan di perairan yang kualitasnya buruk menyebabkan kehadiran ektoparasit (Galli et al., 2001), meningkatnya jumlah ektoparasit (Ojwala et al., 2018) sehingga infeksi ektoparasit menyebabkan kematian (Poulin, 1992), anggota tubuh ikan rusak (Putri dkk., 2016), stress (Putra dkk., 2018) dan acaman terhadap ketahanan pangan (Quiazon, 2015).

Pengetahuan tentang identifikasi ektoparasit pada ikan merupakan hal yang mendasar dan penting, karena jenis penyakit yang seringkali dijumpai berpotensi menjadi kendala pada budidaya (El Amin dan Al-Harbi, 2016; Ojwala et al., 2018) maupun habitat alami ikan (Galli et al., 2001; Sari dan Ekawaty, 2019). Lebih lanjut, informasi parasit, seperti keanekaragaman dan prevalensi kehadiran ektoparasit pada ikan di Situ Gintung belum tersedia. Berdasarkan hal tersebut, tujuan penelitian ini adalah untuk mengetahui kimia fisik perairan, jenis-jenis ektoparasit, prevalensi ektoparasit dan hubungan ektoparasit ikan dengan kimia fisik perairan Situ Gintung, Tangerang Selatan.

\section{Metode Penelitian}

\subsection{Waktu dan Lokasi Penelitian}

Situ Gintung terletak di Tangerang Selatan, Banten (Gambar 1) telah difungsikan untuk rekreasi, memancing, budidaya ikan atau keramba jaring apung (KJA) dan lainnya. Penelitian ini dilaksanakan dalam dua periode dimana periode pertama pada bulan Maret 2018 dengan lokasi pengambilan sampel berada di dua titik dan periode kedua pada bulan Mei hingga Juni 2018 dengan tiga titik untuk pengukuran faktor fisik. Sampel yang diambil kemudian diamati di Laboratorium Ekologi, Pusat Laboratorium Terpadu, UIN Syarif Hidayatullah.

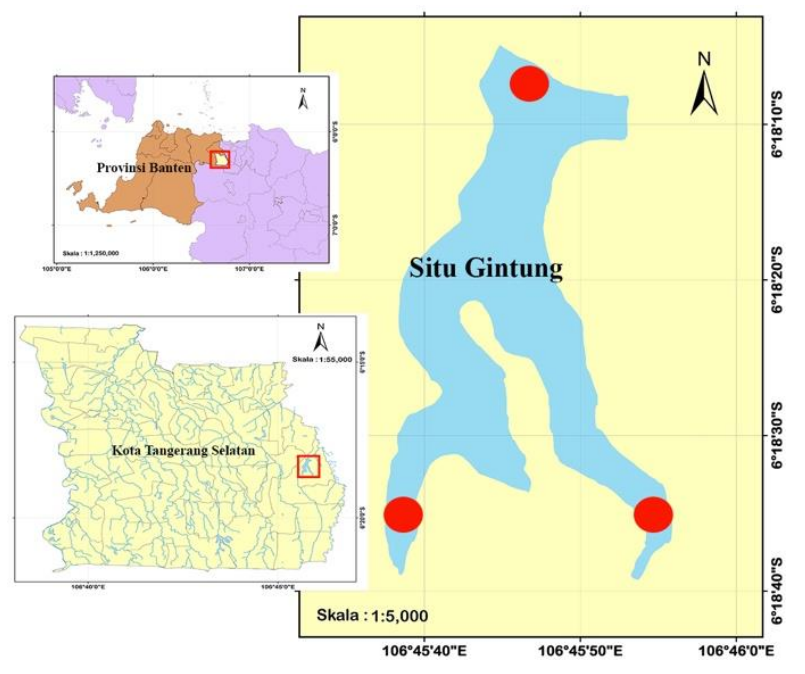

Gambar 1. Lokasi pengambilan sampel

\subsection{Pengambilan Data}

\subsubsection{Persiapan}

Survei lapangan dengan teknik pengumpulan data melalui wawancara dan studi literatur untuk mengetahui mengenai informasi data ikan, jumlah tambak, asal benih ikan, usia benih ikan dan letak tambak di Situ Gintung kepada kelompok PEJABAT (Petani Jaring Apung) serta melihat langsung pemancing ikan. Informasi yang didapat bahwa jenis ikan yang dibudidayakan adalah ikan nila dan patin.

\subsubsection{Pengambilan Sampel}

Metode pengambilan sampel yang digunakan adalah random sampling. Sampel KJA diambil di dua titik yang berada di area inlet, yakni di area tambak kelompok 1 (dekat inlet) dan area tambak gabungan kelompok 2 dan 3 karena jarak tambak kelompok 2 dan 3 berdekatan untuk periode pertama. Pada saat pengambilan sampel di KJA, benih ikan telah berumur 1-2 minggu. Sampel ikan pancing diambil di tiga titik yakni di inlet dan titik pemancingan (berdekatan dengan inlet) untuk periode kedua. Kimia fisik perairan mempengaruhi kehadiran ektoparasit ikan 
(Poulin, 1992; Galli et al., 2001; El Amin dan AlHarbi 2016; Ojwala et al., 2018), untuk itu faktor kimia fisik perairan diambil di masing-masiang titik kemudian diukur DO, BOD, pH, TDS, EC, Turbiditas dan suhu dengan WQC (Horiba U50), kecerahan menggunakan Secchi disk di kedua periode kecuali nitrat, nitrit, amonia, fosfat dan COD (Chemical Oxygen Demand) (APHA, 2005) yang dilakukan pada periode I. Keberadaan ektoparasit ikan dipengaruhi oleh ukuran tubuh (Alifuddin dkk., 2002; Barkah, 2014). Berdasarkan hal tersebut, sampel yang diambil di setiap titik adalah ikan nila dan patin dengan rentang usia 1-2 minggu adaptasi (sejak benih ditebar) yang berasal dari keramba jaring apung dan ikan nila ukuran $10-15 \mathrm{~cm}$ yang berasal dari ikan pancing sebanyak 5 sampai 10 ekor per spesies di setiap titik sampling (Kadarsah $d k k ., 2017)$. Sampel ikan yang didapat kemudian dibawa ke laboratorium dan dipindahkan ke akuarium untuk selanjutnya dianalisis.

\subsubsection{Analisis Sampel}

Bagian tubuh ikan memiliki perbedaan jumlah ektoparasit (Wildani dkk., 2017; Dewi et al., 2018), sehingga analisis sampel dilakukan pada bagian lendir luar tubuh dan insang ikan. Lendir diambil dari permukaan tubuh ikan, kepala sampai ekor menggunakan cover glass dengan metode scrap, dilakukan tiga kali pengulangan. Setelah lendir terambil dengan cover glass, kemudian cover glass diletakkan di atas object glass. Analisis bagian insang ikan dengan cara filamen insang diambil menggunakan pinset kemudian diletakkan di atas object glass dan ditetesi akuades hingga terendam dan ditutup dengan cover glass (Noga, 2010). Kedua bagian tersebut kemudian diamati dengan mikroskop dan di identifikasi dengan merujuk Kabata (1985) dan Noga (2010).

\subsubsection{Analisis Data}

Jenis dan jumlah ektoparasit dianalisis secara deskriptif untuk dihitung prevalensi dan intensitas parasit dengan rumus sebagai berikut (Poulin dan Rohde, 1997):

$$
\begin{aligned}
& \text { Prevalensi } \frac{\text { Jumlalikanyangterinfeksparasit }}{\text { jumlahampelikanyangdiamati }} \times 100 \% \\
& \text { Intensita }=\frac{\text { jumlahtotalparasityangmenginfelis }}{\text { jumlalsampelikanyangterinfeksi }}
\end{aligned}
$$

Uji statistik untuk membedakan data jumlah ektoparasit antara ikan nila dengan patin digunakan MANOVA dan hubungan kimia fisik perairan dengan ektoparasit digunakan analisis Canonical Correspondence Analysis (CCA) (Ter Braak dan Verdonschot, 1995). Analisis statistik menggunakan software Past3 (Hammer et al., 2001).

\section{Tabel 1}

Rata-rata nilai kimia fisik perairan

\begin{tabular}{ccc}
\hline \multirow{2}{*}{ Parameter } & \multicolumn{2}{c}{ Stasiun } \\
\cline { 2 - 3 } & KJA & Pancing \\
\hline Suhu $\left({ }^{\circ} \mathrm{C}\right)$ & 27,64 & 26,96 \\
$\mathrm{pH}$ & 7,47 & 6,55 \\
DO $(\mathrm{mg} / \mathrm{L})$ & 8,31 & 8,84 \\
TDS $(\mathrm{g} / \mathrm{L})$ & 0,10 & 0,11 \\
EC $(\mathrm{mS} / \mathrm{cm})$ & 0,16 & 0,17 \\
Turbiditas $(\mathrm{NTU})$ & 62,00 & 105,46 \\
COD $(\mathrm{mg} / \mathrm{L})$ & 45,33 & TD \\
Nitrat $(\mathrm{mg} / \mathrm{L})$ & 3,00 & TD \\
Nitrit $(\mathrm{mg} / \mathrm{L})$ & Negatif & TD \\
Amonia $(\mathrm{mg} / \mathrm{L})$ & 2,33 & TD \\
Fosfat $(\mathrm{mg} / \mathrm{L})$ & 0,25 & TD
\end{tabular}

Catatan: Negatif menunjukkan bahwa nilai berada dibawah ambang batas; TD adalah tidak ada data.

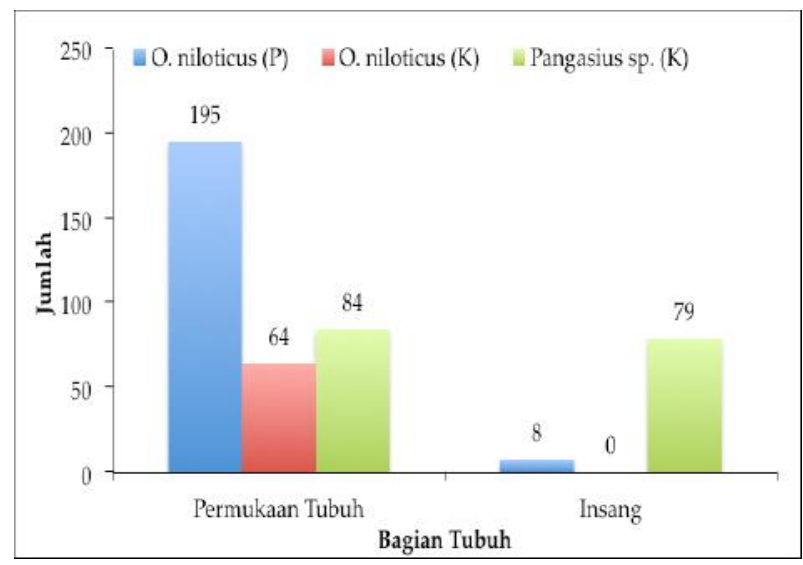

Gambar 2. Jumlah ektoparasit ikan di bagian tubuh (Keterangan: P adalah Pancing dan K adalah Keramba)

\section{Hasil}

Kimia fisik perairan penelitian di Situ Gintung ditunjukkan pada Tabel 1. Rata-rata kimia fisik perairan tertinggi suhu $27,64{ }^{\circ} \mathrm{C}, \mathrm{pH} 7,47, \mathrm{DO} 8,84$ $\mathrm{mg} / \mathrm{L}$, TDS 0,11 g/L, EC 0,17 mS/cm, Turbiditas $105,46 \mathrm{~g} / \mathrm{L}$, nitrat $3 \mathrm{mg} / \mathrm{L}$, nitrit memiliki nilai negatif, amonia $2,33 \mathrm{mg} / \mathrm{L}$, fosfat $0,25 \mathrm{mg} / \mathrm{L}$ dan COD 45,33 mg/L (Tabel 1). 
Tabel 2

Jenis prevalensi ektoparasit pada ikan nila (Oreochromis niloticus) di KJA dan tangkapan pancing.

\begin{tabular}{cccccc}
\hline No & Lokasi & Ektoparasit & N & n & P \\
\hline 1 & Keramba & Trichodina sp. & 7 & 10 & $70 \%$ \\
2 & Tangkapan & Trichodina sp. & 5 & 9 & $55,56 \%$ \\
& & Chilodonella sp. & 2 & 9 & $22,23 \%$ \\
\hline
\end{tabular}

Keterangan: $N=$ Jumlah sampel yang diperiksa, $n=$ Jumlah sampel terinfeksi dan $P=$ Prevalensi

Tabel 3

Jenis dan prevalensi ektoparasit ikan Patin (Pangasius sp.) dari keramba jaring apung.

\begin{tabular}{ccccc}
\hline No & Jenis Ektoparasit & N & n & P \\
\hline 1 & Chilodonella sp. & 10 & 7 & $70 \%$ \\
2 & Litonotus sp. & 10 & 2 & $20 \%$ \\
3 & Vorticella sp. & 10 & 1 & $10 \%$ \\
4 & Dactylogyrus sp. & 10 & 7 & $70 \%$ \\
5 & Capillaria sp. & 10 & 2 & $20 \%$ \\
\hline
\end{tabular}

Keterangan: N=Jumlah sampel yang diperiksa, $n=$ Jumlah sampel terinfeksi dan $P=$ Prevalensi

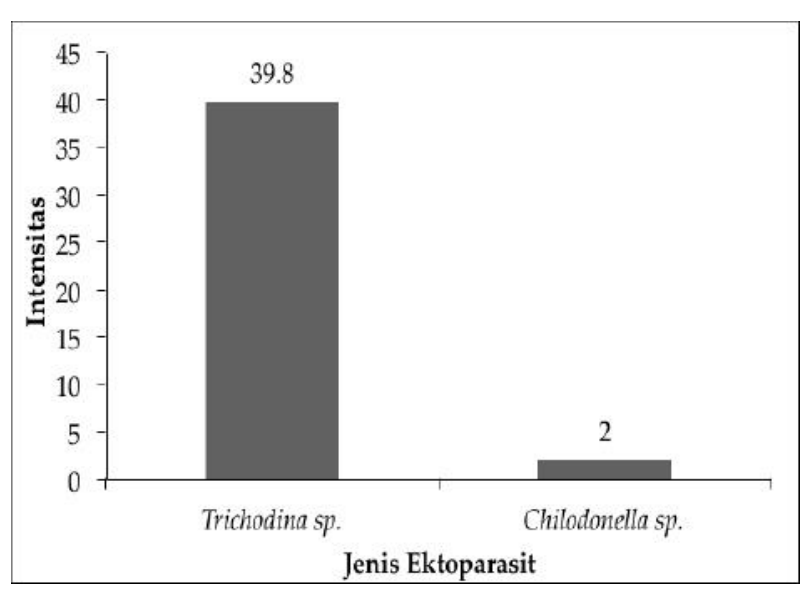

Gambar 3. Intensitas ektoparasit ikan Nila tangkapan pancing.

\subsection{Jenis dan Jumlah Ektoparasit}

Hasil analisis MANOVA untuk jumlah dan jenis ekotoparasit ikan menunjukkan tidak berbeda nyata ( $p>0.05$ ). Jumlah dan jenis ektoparasit ikan hasil budidaya memiliki perbedaan dimana permukaan tubuh lebih banyak jumlahnya dibandingkan dengan hasil pancing, sedangkan jenis ektoparasit sebaliknya (Gambar 2). Jenis ektoparasit yang menginfeksi ikan nila (Oreochromis niloticus) hasil tangkapan di Situ Gintung adalah Trichodina sp. dan Chilodonella sp. dengan prevalensi $55,56 \%$ dan $22,23 \%$. Sedangkan pada ikan nila dari keramba Situ Gintung hanya ditemukan ektoparasit dari jenis Trichodina sp. dengan prevalensi yang lebih tinggi yaitu $70 \%$ (Tabel 2). Intensitas ektoparasit yang ditunjukkan dalam Gambar 3 menunjukkan bahwa ektoparasit dengan intensitas terbesar pada ikan nila tangkapan ialah Trichodina sp. dengan nilai $39,8 \%$ yang artinya setiap satu ekor ikan nila tangkapan Situ Gintung terinfeksi oleh hampir 40 ektoparasit Trichodina sp. Pada ikan patin yang diambil dari keramba jaring apung ditemukan 5 jenis ektoparasit dengan tingkat prevalensi ditunjukkan pada Tabel 3. Prevalansi ektoparasit yang tertinggi adalah Chilodonella sp. dan Dactylogyrus sp. dan terendah Vorticella sp. dengan nilai masing-masing $70 \%$ dan $10 \%$.

\subsection{Ektoparasit dengan Kimia Fisik Perairan}

Hubungan jenis ektoparasit dengan kimia fisik perairan ditunjukkan pada Gambar 4. Berdasarkan hasil Canonical Correspondence Analysis (CCA) menunjukkan bahwa Trichodina sp. dipengaruhi suhu dan turbiditas, Chilodonella sp. dipengaruhi DO, EC dan TDS sedangkan Litonotus sp., Vorticella sp. dan Dactylogyrus sp. dipengaruhi $\mathrm{pH}$.

\section{Pembahasan}

Perairan Situ Gintung memiliki nilai kisaran kualitas kimia fisika air yang masih mampu ditoleransi oleh ikan dan ektoparasit. Nilai suhu dan $\mathrm{pH}$ perairan Situ Gintung tergolong cukup baik untuk kehidupan ikan. Suhu mempunyai peranan penting dalam menentukan pertumbuhan ikan, kisaran yang baik untuk menunjang pertumbuhan optimal organisme perairan adalah 
28-32 ${ }^{\circ} \mathrm{C}$ (Tatangnindatu dkk., 2013) dengan suhu yang optimum untuk ikan nila dilaporkan mulai dari 18-32 ${ }^{\circ} \mathrm{C}$ dan pH 5-9 (El Amin dan Al-Harbi, 2016; Ojwala et al., 2018), sedangkan nilai pH yang ideal untuk kehidupan organisme air pada umumnya adalah 7-8,5 (Barus, 2004). Berdasarkan standar baku mutu air PP No. 82 tahun 2001, pH yang baik untuk kegiatan budidaya ikan air tawar berkisar antara 6-9. $\mathrm{pH}$ yang sangat rendah, menyebabkan kelarutan logam-logam dalam air makin besar, sehingga bersifat toksik bagi organisme air, sebaliknya $\mathrm{pH}$ yang tinggi dapat meningkatkan konsentrasi amonia dalam air yang juga bersifat toksik bagi organisme air (Tatangnindatu $d k k ., 2013)$. Suhu dan $\mathrm{pH}$ perairan Situ Gintung memiliki kisaran yang stabil dan tidak terpengaruh terhadap musim dan keberadaan KJA (El Amin dan Al-Harbi, 2016).

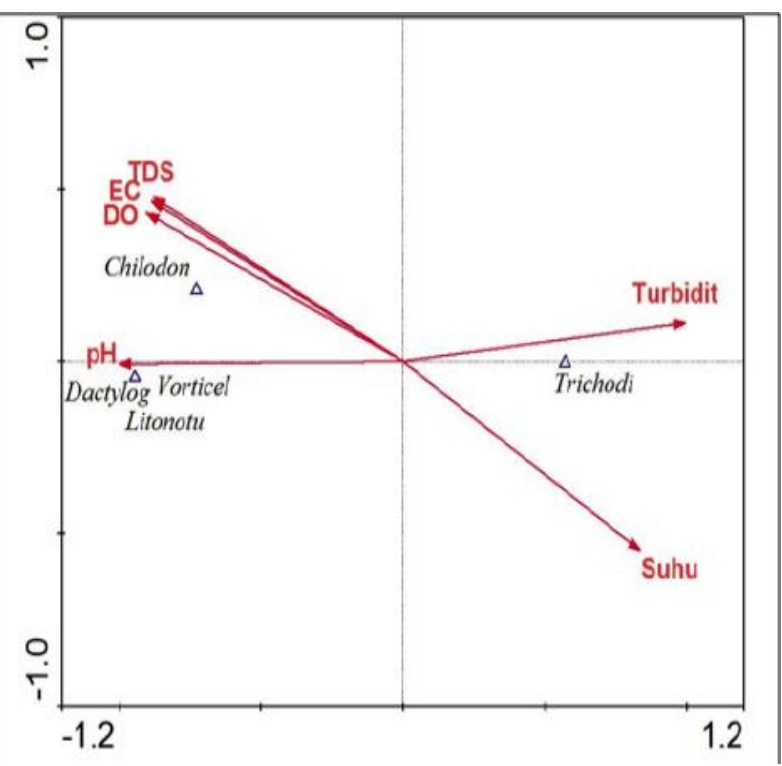

Gambar 4. Canonical Correspondence Analysis (CCA) ektoparasit dengan kimia fisik perairan.

Nilai DO Situ Gintung memiliki nilai kisaran dengan penelitian sebelumnya dimana ikan nila dapat hidup (El Amin dan Al-Harbi, 2016; Ojwala et al., 2018) dan sesuai dengan standar baku mutu dengan batas minimum DO untuk kriteria air untuk budidaya ikan adalah minimal 4 (PP No. 82 Tahun 2001). DO di KJA dan lokasi pancing tidak berbeda nyata (MANOVA, $p>0.05$ ), hal ini karena kedua lokasi dekat dengan inlet dan suhu yang tidak berbeda. Menurut Ojwala et al., (2018) bahwa suhu berkorelasi dengan DO sehingga nilai nya dapat saling mempengaruhi satu sama lain. Nilai TDS masih di bawah standar baku mutu yang disyaratkan dan berada dalam kisaran penelitian sebelumnya (Thakur et al., 2013; Assuyuti dkk., 2017). Berdasarkan standar baku mutu air PP no 82 tahun 2001, kisaran TDS untuk kegiatan budidaya ikan yaitu $1000 \mathrm{mg} / \mathrm{L}$. Nilai TDS menunjukkan adanya aktivitas manusia, semakin tinggi nilai TDS maka semakin tinggi masukkan nutrien. Hasil penelitian sebelumnya menunjukkan bahwa TDS dipengaruhi oleh adanya aktifitas manusia (Thakur et al., 2013) dan musim (Assuyuti dkk., 2017).

Nilai hasil pengukuran konduktivitas (EC) pada penelitian ini berkisar antara 0,15 - 0,19 $\mathrm{mS} / \mathrm{cm}$. Hasil dari nilai konduktivitas, perairan Situ Gintung mempunyai kadar residu terlarut yang tidak terlalu besar, sehingga masih memenuhi persyaratan untuk digunakan sebagai air budidaya (Afriansyah dkk., 2016). Nilai COD (Chemical Oxygen Demand) di area KJA dan pancing masuk kedalam kelas III dimana diperuntukkan budidaya ikan air tawar (PP no. 82 Tahun 2001). Nilai COD di Situ Gintung memiliki kisaran yang sama dengan danau Sangatta North, Kalimantan Timur dengan nilai 5,57 ppm yang dapat dimanfaatkan untuk kepentingan sarana rekreasi air, pembudidayaan ikan air tawar, peternakan dan pengairan pertanian (Santoso, 2018).

Hasil pengukuran nitrat pada perairan Situ Gintung menunjukkan hasil berada dibawah standar baku mutu (Tabel 1) PP No. 82 Tahun 2001 dan masuk kisaran di penelitian sebelumnya (El Amin dan Al-Harbi, 2016). Pemberian pakan yang tinggi mengakibatkan terjadinya proses akumulasi bahan organik berupa sisa pakan dan feses ikan pada sistem akan menyebabkan terjadinya pembentukan senyawa seperti amonia (Pudjiastuti dkk., 2013

Berdasarkan standar baku mutu air PP. No 82 Tahun 2001 untuk kegiatan budidaya ikan air tawar nilai nitrat yang ditentukan yaitu $10 \mathrm{mg} / \mathrm{L}$. Nitrat $\left(\mathrm{NO}_{3}\right)$ adalah bentuk utama nitrogen di perairan alami dan merupakan sumber nutrisi utama bagi pertumbuhan fitoplankton dan tumbuhan air lainnya. Kadar nitrat yang lebih dari $5 \mathrm{mg} / \mathrm{L}$ menggambarkan telah terjadinya pencemaran yang juga berdampak pada keberadaan ikan. Sedangkan nilai fosfat pada perairan Situ Gintung memiliki nilai lebih tinggi dari standar baku mutu yang ditetapkan. Batas maksimum fosfat berdasarkan standar baku mutu air (PP. No 82 Tahun 2001) kelas II yaitu sebesar $0,2 \mathrm{mg} / \mathrm{L}$. Fosfat yang masuk ke perairan dari 
aktivitas budidaya ikan berasal dari sisa pakan pellet yang terbuang (Tatangnindatu $d k k$., 2013) dan buangan aktifitas manusia seperti deterjen.

Jenis parasit yang menginfeksi ikan diantaranya Trichodina sp., Ichthyophthirius multifiliis, Vorticella sp., Gyrodactylus sp., Dactylogyrus sp., dan Cichlidogyrus sp. yang masing-masing didapatkan pada insang, mucus, kulit dan sisik (Rahmi, 2012; Putri dkk., 2016; Nurhalimah 2017). Lebih lanjut, ikan yang terserang parasit akan menjadi lemah dengan warna tubuh yang kusam dan pucat, nafsu makan ikan turun sehingga ikan menjadi kurus (Rahmi, 2012), produksi lendir berlebihan dan terdapat jamur pada sirip punggung (Putri dkk., 2016). Ektoparasit ikan nila Trichodina sp. dan Chilodonella sp. yang ditemukan dalam penelitian ini merupakan ektoparasit yang biasa ditemukan pada kulit dan insang ikan air tawar (Padua et al., 2013; Nurhalimah, 2017; Sari dan Ekawaty 2019). Selain itu, kehadiran kedua ektoparasit tersebut dipengaruhi kimia fisik perairan (Gambar 4). Menurut Ojwala et al., (2018) Trichodina sp. dan Chilodonella sp. dipengaruhi suhu, $\mathrm{pH}, \mathrm{DO}$, total nitrogen (TN) dan nitrat.

Ektoparasit ikan patin dari filum Protozoa yang memiliki nilai prevalensi paling tinggi adalah Chilodonella sp. Nilai prevalensi Chilodonella sp. yang tinggi karena parasit ini dengan cepat berkembangbiak dengan membelah diri dan menular ke ikan lain (Amirullah dkk., 2012) dan DO perairan yang mendukung (Ojwala et al., 2018). Lebih lanjut, filum Protozoa mempunyai siklus hidup dan reproduksi yang cepat, karena beberapa spesies Protozoa dalam kondisi optimal dapat berkembangbiak dalam waktu \pm 24 jam. Infeksi Chilodonella sp. pada inang menyebabkan lapisan epithel inang mengalami kerusakan dan menghilangkan lendir, karena parasit ini memakan sel epitel (Cahyono dkk., 2006). Parasit tidak memiliki inang spesifik dan menyebabkan lesi pada inang yang terinfeksi Chilodonella sp. (Padua et al., 2013). Menurut Utami (2012), Chilodonella sp. menginfeksi secara berkelompok atau koloni sehingga sering kali ektoparasit ini ditemukan dalam jumlah banyak, ketika terjadi penurunan temperatur ikan akan mudah terinfeksi Chilodonella sp.

Genus ektoparasit dari filum Helminthes yang yang memiliki nilai prevalensi paling tinggi adalah Dactylogyrus sp. dengan nilai prevalensi sebesar $70 \%$ yang ditemukan di insang (Tabel 3) dan dipengaruhi $\mathrm{pH}$ (Gambar 4). Menurut Amirullah dkk., (2012), insang dapat menyediakan sumber makanan berupa darah dan media yang cocok bagi Dactylogyrus untuk dapat bereproduksi secara maksimal, berkembangbiak dengan cepat dan tidak memiliki inang spesifik sehingga dapat menginfeksi semua jenis ikan. Lebih lanjut, Dactylogyrus ditemukan $\mathrm{pH}$ perairan yang asam sampai dengan netral (El Amin dan Al-Harbi, 2016) dan sensitif terhadap konsentrasi $D O$, feacal coliform dan total nitrogen (Lacerda et al., 2018). Selain Chilodonella dan Dactylogyrus genus ektoparasit yang ditemukan pada ikan patin di Keramba Jaring Apung (KJA) Situ Gintung adalah Litonotus yang memiliki nilai prevalensi sebesar $20 \%$. Hasil penelitian sebelumnya Litonotus sp. tidak ditemukan (Amirullah dkk., 2012; Wildani dkk., 2017) karena biasanya ditemukan dalam sistem pengolahan limbah secara aerob (Hidayat, 2016).

Vorticella sp. juga ditemukan pada ikan patin di Keramba Jaring Apung (KJA) Situ Gintung dengan nilai prevalensi terkecil yaitu hanya $10 \%$. Hasil penelitian sebelumnya menunjukkan bahwa Vorticella sp. di ikan sungai yang ditemukan sedikit (Sari dan Ekawaty, 2019). Vorticella sp. termasuk dalam golongan protozoa dari filum Ciliophora, genus ini dapat hidup di air tawar dan di air laut serta dapat menempel di tumbuhan atau hewan (Kabata, 1985). Vorticella sp juga dapat dijumpai dalam flok yang terbentuk pada sistem pengolahan limbah cair (Hidayat, 2016) dan dipengaruhi $\mathrm{pH}$ perairan (Gambar 4).

Capillaria sp. ditemukan pada ikan patin yang berasal dari Keramba Jaring Apung Situ Gintung, genus ini termasuk dalam jenis cacing dari filum nematoda. Cacing Capillaria sp. merupakan parasit pada permukaan sistem pencernaan dan juga pada hati ikan (Noga, 2010). Menurut Dewi et al., (2018) Capillaria sp. ditemukan di bagian abdomen ikan dengan persentasi yang rendah. Pada infestasi ringan Capillaria sp. sering tidak menimbulkan gejala-gejala yang berarti. Sedangkan pada infestasi berat biasanya ditandai dengan gejala "emaciation" atau badan kurus, kehilangan nafsu makan, mengeluarkan kotoran berwarna putih dan tipis, atau kotoran dengan warna berselangseling antara gelap (hitam) dan terang (putih). Kehadiran Capillaria sp. biasanya disebabkan oleh penularan dari ikan lain yang telah terinfeksi sebelumnya. Capillaria sp. tidak memerlukan inang tertentu, sehingga infeksi hanya bisa dilakukan oleh ikan lain yang terinfeksi. 


\section{Kesimpulan}

Kimia fisik perairan Situ Gintung memiliki nilai standar baku mutu untuk budidaya perikanan. Jumlah dan jenis ektoparasit berbeda antara ikan hasil pancing dan keramba jaring apung (KJA) dimana jumlah ektoparasit lebih banyak di ikan hasil pancing sedangkan jenis lebih banyak dari KJA.

\section{Ucapan terimakasih}

Terimakasih kepada Lembaga Penelitian dan Pengabdian Masyarakat (LP2M) UIN Syarif Hidayatullah (Nomor UN.01/KPA/229/2018) yang telah membiayai penelitian ini.

\section{Daftar Pustaka}

Afriansyah, Dewiyanti, I., \& Hasri, I. (2016). Keragaman Nitrogen dan T-Phosfat pada pemanfaatan limbah budidaya Ikan Lele (Clarias gariepinus) oleh Ikan Peres (Osteochilus kappeni) dengan sistem resirkulasi. Jurnal Ilmiah Mahasiswa Kelautan dan Perikanan Unsyiah, 2, 252-261.

Alifuddin, M., Priyono, A., \& Nurfatihah, A. (2002). Inventarisasi parasit pada ikan hias yang dilalulintaskan di Bandara Soekarno-Hatta, Cengkareng, Jakarta. Jurnal Akualkultur Indonesia, 1(3), 123-127.

Amirullah, S., Dhahiyat, Y., \& Rustikawati, I. (2012). Intensitas dan Prevalensi Ektoparasit pada Ikan di Hulu Sungai Cimanuk Kabupaten Garuk Jawa Barat. Jurnal Perikanan dan Kelautan, 3(4), 271-282.

APHA. (2005). Standard methods for the examination of water and wastewater. (21 $\left.{ }^{\text {st }} \mathrm{Ed}\right)$. USA.

Assuyuti, Y. M., Rijaluddin, A. F., Ramadhan, F., Zikrillah, R. B., \& Kusuma, D. C. (2017). Struktur komunitas dan distribusi temporal gastropoda di Danau Situ Gintung, Tangerang Selatan, Banten. Scripta Biologica, 4(3), 139-146.

Bahri, S., Ramadhan, F., \& Reihannisa, I. (2015). Kualitas Perairan Situ Gintung Tangerang Selatan. Biogenesis, 3, 16-22.

Barkah, W. T. (2014). Keberadaan ektoparasit pada Gurame Osphronemus goramy yang dibudidayakan secara tradisional serta analisis korelasi aspek biologi inangparasit. Skripsi. Bogor, Indonesia: Institut Pertanian Bogor (IPB).

Barus, T. A. (2004). Pengantar Limnologi Studi Tentang Ekosistem Air Daratan. Medan, Indonesia: USU Press.

Cahyono, P. M., Mulia D. S., \& Rochmawati E. (2006). Identifikasi ektoparasit protozoa pada benih ikan Tawes (Puntius javanicus) di balai benih ikan Sidabowa Kabupaten Banyumas dan Balai Benih Ikan
Kutasari Kabupaten Purbalingga. Jurnal Protein, 13(2), 181-187.

Cai, Y., Gong, Z., \& Qin, B. (2012). Benthic macroinvertebrate community structure in Lake Taihu, China: Effects of trophic status, wind-induced disturbance and habitat complexity. Journal of Great Lakes Research, 38, 39-48.

Chen, Y., Zhao, K., Wu, Y., Gao, S., Cao, W., Bo, Y., Shang, Z., Wu, J. \& Zhou, F. (2016). Spatio-temporal patterns and source identification of water pollution in lake taihu (China). Water, 8(3), 1-11.

Dewi, R. R., Desrita, D., \& Fadhilla, A. (2018). The prevalence of parasites in ornamental fish from fish market in Medan. IOP Conference Series: Earth and Environmental Science, 122(1), 012110.

El Amin, M. S., \& Al-Harbi, A. H. (2016). Prevalence and seasonal variation of ectoparasites in cultured Nile tilapia Oreochromis niloticus in Saudi Arabia. Journal of parasitic diseases, 40(4), 1487-1493.

Galli, P., Crosa, G., Mariniello, L., Ortis, M., \& D'amelio, S. (2001). Water quality as a determinant of the composition of fish parasite communities. Hydrobiologia, 452(1-3), 173-179.

Hammer, Ø., Harper, D. A. T., \& Ryan, P. D. (2001). PAST: paleontological statistics software package for education and data analysis. Palaeontologia Electronica, $4(1), 9$.

Hidayat, A., Marits, D. M., \& Gandhi, P. (2016). Analisis kelembagaan pengelolaan perikanan tangkap di waduk Cirata. Jurnal Risalah Kebijakan Pertanian dan Lingkungan, 3(2), 1-21.

Kabata, Z. (1985). Parasites and diseases of fish cultured in the tropics. London: Taylor \& Francis.

Kadarsah, A., Muhamat, M., \& Hidayaturrahmah, H. (2017). Keanekaragaman jenis dan prevalensi ektoparasit pada lima jenis ikan komersial di Desa Sungai Batang Kecamatan Martapura Barat. Bioscientiae, 14(1), 1-8.

Kagalou, I., Petridis, D., \& Tsimarakis, G. (2003). Seasonal variation of water quality parameters and plankton in a shallow Greek lake. Journal of Freshwater Ecology, 18(2), 199-206.

Lacerda, A. C. F., Roumbedakis, K., Junior, J. B., Nuñer, A. P. O., Petrucio, M. M., \& Martins, M. L. (2018). Fish parasites as indicators of organic pollution in southern Brazil. Journal of Helminthology, 92, 322-331.

Lange, C. N., Kristensen, T. K., \& Madsen, H. (2013). Gastropod diversity, distribution and abundance in habitats with and without anthropogenic disturbances in Lake Victoria, Kenya. African Journal of Aquatic Science, 38(3), 295-304.

Noga, E. J. (2010). Fish Disease: Diagnosis and Treatment. ( $2^{\text {nd }}$ Ed). USA: Wiley-Blackwell Publishing.

Nurhalimah, N. (2017). Inventarisasi ektoparasit pada pendederan ikan Nila merah Oreochromis sp. yang 
dipelihara pada fasilitas kolam percobaan FPIK IPB. Skripsi. Bogor, Indonesia: Institut Pertanian Bogor (IPB).

Ojwala, R. A., Otachi, E. O., \& Kitaka, N. K. (2018). Effect of water quality on the parasite assemblages infecting Nile tilapia in selected fish farms in Nakuru County, Kenya. Parasitology research, 117(11), 3459-3471.

Pádua, S. B., Martins, M. L., Carrijo-Mauad, J. R., Ishikawa, M. M., Jerônimo, G. T., Dias-Neto, J., \& Pilarski, F. (2013). First record of Chilodonella Hexasticha (Ciliophora: Chilodonellidae) in Brazilian cultured fish: A morphological and pathological assessment. Veterinary Parasitology, 191(1-2), 154-160.

Poulin, R. (1992). Toxic pollution and parasitism in freshwater fish. Parasitology Today, 8(2), 58-61.

Poulin, R., \& Rohde, K. (1997). Comparing the richness of metazoan ectoparasite communities of marine fishes: controlling for host phylogeny. Oecologia, 110(2), 278-283.

Pujiastuti, P., Ismail, B., \& Pranoto, P. (2013). Kualitas Dan Beban Pencemaran Perairan Waduk Gajah Mungkur. Jurnal Ekosains, 5(1) : 59-75.

Putra, E. M., Mahasri, G., \& Sari, L. A. (2018). Infestasi ektoparasit pada ikan nila (Oreochromis niloticus) yang dipelihara dengan menggunakan sistem akuaponik dan tanpa akuaponik. Journal of Aquaculture and Fish Health, 7(1), 42-49.

Putri, S. M., Haditomo, A. H. C., \& Desrina, D. (2016). Infestasi monogenea pada ikan konsumsi air tawar di kolam budidaya Desa Ngrajek Magelang. Journal of Aquaculture Management and Technology, 5(1), 162-170.

Quiazon, K. M. A. (2015). Updates on aquatic parasites in fisheries: implications to food safety, food security and environmental protection. Journal of Coastal Zone Management, 18(1), 396.

Rahmi, R. (2012). Identifikasi ektoparasit pada ikan Nila (Oreochromis niloticus) yang dibudidayakan pada tambak Kabupaten Maros. Jurnal Octopus, 1(1), 19-23.

Reynaud, A., \& Lanzanova, D. (2017). A Global MetaAnalysis of the Value of Ecosystem Services Provided by Lakes. Ecological Economics, 137, 184-194.

Sari, A. H. W., \& Ekawaty, R. (2019). Inventarisasi dan komposisi jenis ektoparasit Ikan Nila (Oreochromis niloticus) sebagai biomonitoring Perairan Sungai
Tukad Badung, Bali. Journal of Marine and Aquatic Sciences, 5(1), 89-93.

Santoso, A. D. (2018). Keragaan Nilai DO, BOD dan COD di danau bekas tambang batu bara: Studi kasus pada Danau Sangatta North PT. KPC di Kalimatan Timur. Jurnal Teknologi Lingkungan, 19(1), 89-96.

Su, L., Xue, Y., Li, L., Yang, D., Kolandhasamy, P., Li, D., \& Shi, H. (2016). Microplastics in Taihu Lake, China. Environmental Pollution, 216, 711-719.

Tatangnindatu, F., Kalesaran, O., \& Rompas, R., (2013). Studi parameter fisika kimia air pada areal budidaya ikan di Danau Tondano, Desa Paleloan, Kabupaten Minahasa. Budidaya Perairan, 2, 8-19.

Ter Braak, C. J., \& Verdonschot, P. F. (1995). Canonical correspondence analysis and related multivariate methods in aquatic ecology. Aquatic Science, 57, 255289.

Thakur, R. K., Jindal, R., Singh, U. B., \& Ahluwalia, A. S. (2013). Plankton diversity and water quality assessment of three freshwater lakes of Mandi (Himachal Pradesh, India) with special reference to planktonic indicators. Environmental Monitoring and Assessment, 185, 8355-8373.

Utami, P. (2012). Keragaman Jenis Ektoparasit Pada Ikan Hasil Tangkapan Di Sungai Banjaran Kabupaten Banyumas. Skripsi. Purwokerto, Indonesia: Fakultas Matematika dan Ilmu Pengetahuan Alam, Unit Program Belajar Jarak Jauh (UPBJJ) Universitas Terbuka Purwokerto.

Wardhana, H. I., Nadila, A., Mardiansyah, M., Ramadhan, F., \& Rijaluddin, A. F. (2017). Kualitas perairan pada bulan Ramadan di Situ Gintung, Tangerang Selatan, Banten. Jurnal Biodjati, 2, 9-20.

Wildani, D., Muttaqien, M., \& Wardani, E. (2017). Identifikasi ektoparasit pada ikan Patin (Pangasius spp.) di tambak budidaya ikan desa Lampeuneurut Kabupaten Aceh Besar. Jurnal Ilmiah Mahasiswa Veteriner, 1(3), 448-455.

Zhang, D., Xie, P., Liu, Y. \& Qiu, T. (2009) Transfer, distribution and bioaccumulation of microcystins in the aquatic food web in lake taihu, china, with potential risks to human health. Science of The Total Environment, 407, 2191-2199.

(C) 2019 by the authors; licensee Udayana University, Indonesia. This article is an open access article distributed under the terms and conditions of the Creative Commons Attribution license (http://creativecommons.org/licenses/by/3.0/). 